\title{
HUBUNGAN AKSES MEDIA MASSA DENGAN PENGETAHUAN KESEHATAN REPRODUKSI REMAJA DISMA NEGERI 5 KOTA TERNATE TAHUN 2016
}

\author{
Rosida Hi. Saraha \\ Politeknik Kesehatan Kementerian Kesehatan Ternate \\ Program Studi Diploma III Kebidanan \\ Email : sidahisaraha@yahoo.co.id
}

\begin{abstract}
ABSTRAK
Pengetahuan tentang kesehatan reproduksi merupakan hal yang penting yang perlu diketahui oleh para remaja namun kenyataannya masih banyak remaja yang belum mengetahui mengenai kesehatan reproduksinya dengan baik padahal pengetahuan tersebut dapat diperoleh dari berbagai sumber yang salah satunya ialah media massa. Tujuan dari penelitian ini adalah menganalisis hubungan akses media massa dengan pengetahuan kesehatan reproduksi pada remaja serta menganalisis hubungan jenis media massa dengan pengetahuan kesehatan reproduksi pada remaja. Metode penelitian observasional dengan rancangan penelitian cross sectional dimana pengambilan sampel secara simple random sampling atau randomisasi sederhana pada siswa kelas XI SMA Negeri 5 yang memenuhi kriteria inklusi dan tidak termasuk dalam kriteria eksklusi dan didapatkan besar sampel yang dibutuhkan sebanyak 45 responden. Responden diberikan angket dan mengisi sendiri angket tersebut dibawah pengawasan peneliti. Uji statistik menggunakan uji chi-square dengan derajat kemaknaan $\mathrm{p}<0,05$. Hasil penelitian ini membuktikan bahwa terdapat hubungan yang signifikan antara akses media massa dengan pengetahuan kesehatan reproduksi pada remaja $(\mathrm{p}=0,110)$ serta terdapat hubungan yang signifikan antara jenis media massa dengan pengetahuan kesehatan reproduksi pada remaja $(\mathrm{p}=0,002)$.Simpulan terdapat hubungan akses media massa dengan pengetahuan kesehatan reproduksi dan terdapat hubungan jenis media massa dengan pengetahuan kesehatan reproduksi.
\end{abstract}

Kata kunci: akses media massa, pengetahuan kesehatan reproduksi, jenis media massa.

\begin{abstract}
ABTRACT
Knowledge about reproductive health is an important thing that needs to be known by adolescents, but in reality there are still many adolescents who do not know about reproductive health properly even though this knowledge can be obtained from various sources, one of which is mass media. The purpose of this study is to analyze the relationship between mass media access and knowledge of reproductive health in adolescents and analyze the relationship between types of mass media and knowledge of reproductive health in adolescents. Observational research method with research design cross sectional where sampling simple random or simple randomization in class XI SMA Negeri 5 students who meet the inclusion criteria and are not included in the exclusion criteria and obtained the required sample size of 45 respondents. Respondents were given a questionnaire and filled out the questionnaire themselves under the supervision of the researcher. Statistical test using chi-square test with significance level $\mathrm{p}<0.05$. The results of this study prove that there is a significant relationship between access to mass media and knowledge of reproductive health in adolescents $(p=0.110)$ and there is a significant relationship between types of mass media with knowledge of reproductive health in adolescents $(\mathrm{p}=0.002)$. The conclusion is that there is a relationship between mass media access and reproductive health knowledge and there is a relationship between the type of mass media and reproductive health knowledge.
\end{abstract}

Keywords: mass media access, reproductive health knowledge, types of mass media 


\section{PENDAHULUAN}

Masa remaja ditandai dengan
pengalaman-pengalaman baru yang sebelumnya belum pernah terbayangkan dan dialami dalam bidang fisik, biologis maupun psikis atau kejiwaan. Pada masa remaja terjadi perkembangan yang dinamis dalam kehidupan individu yang ditandai dengan percepatan pertumbuhan fisik, emosional, dan sosial. Perubahan fisik yang terjadi di antaranya timbul proses pematangan organ reproduksi seperti menstruasi pertama bagi kaum wanita dan keluarnya sperma bagi kaum pria yang merupakan tonggak pertama dalam perjalanan usia remaja yang indah dan penuh tanda tanya. Hal ini mengakibatkan perubahan sikap dan tingkah laku seperti mulai memperhatikan penampilan diri, mulai tertarik dengan lawan jenis, berusaha menarik perhatian dan muncul perasaan cinta yang kemudian akan timbul dorongan seksual (Basri hasan, 1996).

Kesalahan persepsi ini sebagian besar terjadi pada remaja putra $49,7 \%$ sedangkan remaja putri $42,3 \%$ serta ditemukan hanya $19,2 \%$ remaja yang sadar akan adanya peningkatan risiko tertular IMS jika memiliki pasangan seksual lebih dari satu dan $51 \%$ dari mereka mengetahui akan berisiko tertular HIV jika melakukan hubungan seksual dengan pekerja seksual komersial. $^{2}$ Data kehamilan remaja di Indonesia menunjukkan remaja yang hamil diluar nikah karena diperkosa sebanyak $3,2 \%$, karena sama-sama mau sebanyak $12,9 \%$ dan tidak terduga sebanyak $45 \%$ serta seks bebas sendiri mencapai 22,6\% (Nasria,2010).

Masalah demografi yang masih menjadi perhatian bagi bangsa Indonesia adalah jumlah penduduk yang sangat besar serta kualitas sumber daya manusia yang masih rendah ditambah kelahiran yang tidak terkendali merupakan faktor penyumbang bagi masalah tersebut. United Nation Population

Fund Ascosiation(UNFPA) dan BKKBN menyebutkan bahwa setiap tahun terdapat sekitar 15 juta remaja berusia 15-19 tahun melahirkan, sekitar 2,3 juta kasus aborsi juga terjadi di Indonesia dimana 20\% nya dilakukan oleh remaja. Fakta lain menunjukkan bahwa sekitar $15 \%$ remaja usia 10-24 tahun yang jumlahnya mencapai 52 juta telah melakukan hubungan seksual diluar nikah. Penelitian PKBI di kota Palembang, Kupang, Tasikmalaya, Cirebon, Singkawang tahun 2005 menyebutkan bahwa $9,1 \%$ remaja telah melakukan hubungan seks dan $85 \%$ nya melakukan hubungan seks pertama mereka pada usia (Bagus Ida, 2004).

Berdasarkan data statistik tahun 2010, jumlah penduduk di Maluku Utara mencapai 32.322.657 jiwa yang terdiri atas $17.225 .464 \quad(53,29 \%)$ laki-laki dan 15.097.193 (46,71\%) perempuan dimana sekitar 5.687.931 atau 17,60\% dari jumlah tersebut adalah remaja sementara jumlah penduduk khususnya di kota Ternate mencapai 1.555.984 jiwa yang terdiri dari 764.487 jiwa laki-laki serta 791.497 jiwa perempuan, dari data tersebut 267.182 jiwa diantaranya merupakan remaja. ${ }^{6,7}$ Jumlah ini adalah jumlah yang relatif cukup besar karena nantinya mereka akan menjadi generasi penerus, untuk itu status atau keadaan kesehatan mereka saat ini akan sangat menentukan kesehatan mereka di saat dewasa nanti (Try, 2008).

Dari berbagai sumber yang peroleh, ada beberapa masalah yang dihadapi oleh remaja yang berhubungan dengan kesehatan yang salah satunya terletak pada area kesehatan reproduksi. Permasalahan tersebut ialah rendahnya pengetahuan tentang kesehatan reproduksi yang benar. Oleh sebab itu, peneliti tertarik untuk meneliti hubungan akses media massa dengan pengetahuan kesehatan reproduksi khususnya bagi para remaja. Pengetahuan kesehatan reproduksi menjadi sangat penting untuk remaja karena saat usia remaja terjadi perkembangan yang sangat dinamis baik secara biologi maupun psikologi serta beberapa faktor yang mempengaruhi pengetahuan remaja seperti informasi yang di terima, orang tua, teman, orang terdekat, media massa dan seringnya 
diskusi sehingga remaja perlu mengetahui kesehatan reproduksi agar memiliki informasi yang benar mengenai proses reproduksi serta berbagai faktor yang ada disekitarnya. Dengan informasi yang benar, diharapkan remaja memiliki sikap dan tingkah laku yang bertanggung jawab mengenai proses reproduksi

\section{Kajian Literatur \\ Pengertian Pengetahuan}

Pengetahuan adalah merupakan hasil dari tahu dan ini setelah orang melakukan penginderaan terhadap obyek tertentu. Penginderaan terjadi melalui panca indera manusia, yakni indera penglihatan, pendengaran, penciuman, rasa dan raba. Sebagaian besar pengetahuan manusia diperoleh melalui mata dan telinga.Berdasarkan pendekatan kontruktivistis, pengetahuan bukanlah fakta dari suatu kenyataan yang sedang dipelajari, melainkan sebagai konstruksi kognitif seseorang terhadap obyek, pengalaman, maupun lingkungannya. Pengetahuan bukanlah sesuatu yang sudah ada dan tersedia dan sementara orang lain tinggal menerimanya. Pengetahuan adalah sebagai suatu pembentukan yang terus menerus oleh seseorang yang setiap saat mengalami reorganisasi karena adanya pemahaman-pemahaman baru (Notoadmodjo, 2010).

\section{Pengertian Media Massa}

Media massa atau pers adalah suatu istilah yang mulai dipergunakan pada tahun1920-anuntuk mengistilahkan jenis media yang secara khusus didesain untuk mencapai masyarakat yang sangat luas. Dalam pembicaraan sehari-hari, istilah ini sering disingkat menjadimedia.Secara umum dipahami bahwa istilah media mencakup sarana komunikasi seperti pers, media penyiaran (broadcasting) dan sinema. Media juga merujuk pada berbagai institusi atau bisnis yang berkomunikasi dengan para audiens, terutama dalam menyediakan pengisi waktu luang/hiburan (Latief abdul dkk, 1985).

\section{Jenis Media Massa}

Seiring dengan berjalannya waktu dan perkembangan teknologi dan sosial budaya, telah berkembang media-media lain yang kemudian dikelompokkan ke dalam media massa seperti internet dan telepon selular. Dalam jenis media ini terdapat ciri-ciri seperti sumber dapat mentransmisikan pesannya kepada banyak penerima (melalui SMS atau internet misalnya), isi pesan tidak hanya disediakan oleh lembaga atau organisasi namun juga oleh individual, tidak ada perantara sehingga interaksi terjadi pada individu, komunikasi mengalir (berlangsung) ke dalam serta penerima yang menentukan waktu interaksi (Burton graeme, 1999).

\section{Pengaruh Media Massa}

Pengaruh media cukup kompleks, dampak bisa dilihat dari skala kecil (individu) dan luas (masyarakat) serta kecepatannya, yaitu cepat (dalam hitungan jam dan hari) dan lambat (puluhan tahun/ abad) dampak itu terjadi. Pengaruh media bisa ditelusuri dari fungsi komunikasi massa, model sederhana yang sering dikutip untuk model komunikasi hingga sekarang, yaitu siapa (who), pesannya apa (says what), saluran yang digunakan (in what channel), kepada siapa (to whom) dan apa dampaknya (with what effect). Model ini adalah garis besar dari elemenelemen dasar komunikasi (Burton graeme, 1999).

\section{Akses media massa}

Masyarakat dengan tingkat ekonomi rendah memiliki ketergantungan dan kebutuhan terhadap media massa yang lebih tinggi daripada masyarakat dengan tingkat ekonomi tinggi karena pilihan mereka yang terbatas. Masyarakat dengan tingkat ekonomi lebih tinggi memiliki lebih banyak pilihan dan akses banyak media massa, termasuk bertanya langsung pada sumber atau ahli dibandingkan mengandalkan informasi yang mereka dapat dari media massa tertentu (Latief abdul dkk, 1985). 


\section{Pengertian Remaja}

Remaja adalah waktu manusia berumur belasan tahun. Pada masa remaja manusia tidak dapat disebut sudah dewasa tetapi tidak dapat pula disebut anakanak. Masa remaja adalah masa peralihan manusia dari anak-anank yang berjalan antara umur 12 tahun sampai 21 tahun.Masa remaja bermula pada perubahan fisik yang cepat, pertambahan berat dan tinggi badan yang dramatis, perubahan bentuk tubuh, dan perkembangan karakteristik seksual seperti pembesaran buah dada, perkembangan pinggang dan kumis, dan dalamnya suara. Pada perkembangan ini, pencapaian kemandirian dan identitas sangat menonjol (pemikiran semakin logis, abstrak, dan idealistis) dan semakin banyak menghabiskan waktu di luar keluarga (BEM FK UNDIP, 2005).

\section{Perubahan yang Terjadi pada Masa Remaja}

Perubahan-perubahan yang terjadi pada saat seorang anak memasuki usia remaja antara lain dapat dilihat dari 3 dimensi yaitu dimensi biologis, dimensi kognitif dan dimensi sosial. Pertama ialah dimensi biologis. Pada saat seorang anak memasuki masa pubertas yang ditandai dengan menstruasi pertama pada remaja putri atau pun mimpi basah pada remaja putra, secara biologis dia mengalami perubahan yang sangat besar. Pubertas menjadikan seorang anak memiliki kemampuan untuk berreproduksi. Kedua ialah dimensi kognitif. Perkembangan kognitif, remaja merupakan periode terakhir dan tertinggi dalam tahap pertumbuhan operasi formal (period of formal operations). Pada periode ini, idealnya para remaja sudah memiliki pola pikir sendiri dalam usaha memecahkan masalah-masalah yang kompleks dan abstrak. Ketiga ialah dimensi moral. Masa remaja adalah periode dimana seseorang mulai bertanya-tanya mengenai berbagai fenomena yang terjadi di lingkungan sekitarnya sebagai dasar bagi pembentukan nilai diri mereka (BEM FK UNDIP, 2005).

\section{Problematika Remaja}

Kenakalan remaja ialah suatu tindakan menyimpang dan dilakukan oleh kelompok remaja dan pemuda yang mendatangkan gangguan terhadap ketenangan dan ketertiban hidup di masyarakat. Menurut etiologi kenakalan remaja (juvenile deliquency) berarti suati penyimpangan tingkah laku yang dilakukan oleh remaja hingga mengganggu ketentraman diri sendiri dan orang lain. Suatu perbuatan dan tingkah laku, perkosaan terhadap norma-norma hukum pidana dan pelanggaran terhadap kesusilaan yang dilakukan oleh anak-anak (Basri hasan, 1996).

\section{METODE PENELITIAN}

Penelitian ini merupakan penelitian observasional dengan rancangan penelitian cross sectional.

\section{HASIL DAN PEMBAHASAN}

Hasil penelitian menunjukkan bahwa terdapat hubungan yang signifikan antara akses media massa dengan pengetahuan kesehatan reproduksi pada remaja $(\mathrm{p}=$ 0,110 ) serta terdapat hubungan yang signifikan antara jenis media massa dengan pengetahuan kesehatan reproduksi pada remaja $(p=0,002)$.

Hubungan akses media massa dengan pengetahuan kesehatan reproduksi pada remaja.

Akibat dari keterbatasan dalam mengakses media massa untuk memperoleh pengetahuan kesehatan reproduksi, maka kemungkinan pengetahuan kesehatan reproduksi yang dimiliki tidak sebanyak remaja yang dapat mengakses media massa dengan mudah. Hasil dari analisis dengan menggunakan uji kolmogorov-smirnov menunjukkan bahwa tidak terdapat hubungan yang signifikan antara akses media massa dengan pengetahuan kesehatan reproduksi pada remaja. Hasil 
penelitian ini didapatkan bahwa mayoritas siswa yang akses media massanya terjangkau memiliki pengetahuan kesehatan reproduksi cukup $(49,33 \%)$ dan baik (22\%) sedangkan siswa yang akses media massanya tidak terjangkau pada umumnya memiliki pengetahuan kesehatan reproduksi kurang dengan nilai signifikan $\mathrm{p}$ adalah 0,110 ( $p>0,05)$.Hasil penelitian ini kurang sesuai dengan hasil penelitian sebelumnya yang dilakukan oleh Tri Prapto Kurniawan (2008) yang menunjukkan bahwa ada pengaruh pengetahuan remaja, sikap remaja, peran orang tua, peran guru serta akses informasi terhadap praktek kesehatan reproduksi remaja tentang puberitas, penyakit IMS, kehamilan tidak dikehendaki (KTD) dan aborsi. Hasil penelitian ini juga kurang sesuai dengan hasil penelitian sebelumnya oleh Rizza Norta (2011) dimana hasil penelitiannya menyatakan bahwa terdapat hubungan antara penggunaan media massa dengan tingkat pengetahuan kesehatan reproduksi (Rizza, 2011).

Berdasarkan hasil penelitian yang tidak signifikan dan kurang sesuai dengan penelitian-penelitian namun seperti yang dijelaskan dalam teori sebelumnya dimana dapat diakibatkan oleh faktor pemungkin lainnya yang dapat mempengaruhi pengetahuan tentang kesehatan reproduksi pada remaja seperti akses terhadap pendidikan kesehatan serta akses terhadap pelayanan kesehatan reproduksi sehingga remaja tidak hanya menggunakan akses media massa sebagai satu-satunya sarana untuk memperoleh pengetahuan kesehatan reproduksi.

\section{Hubungan jenis media massa dengan pengetahuan kesehatan reproduksi pada remaja.}

Pengetahuan yang dapat diperoleh dari informasi yang diberikan melalui media massa seperti media cetak dan media elektronik dapat mencakup banyak hal, salah satunya ialah pengetahuan tentang kesehatan reproduksi. Sujamati menyatakan bahwa media massa baik cetak maupun elektronik mempunyai peranan yang cukup berarti untuk memberikan informasi tentang pengetahuan kesehatan reproduksi khususnya bagi para remaja (Suhanjati, 2003). Hasil dari analisis dengan menggunakan uji kolmogorovsmirnov menunjukkan bahwa terdapat hubungan yang signifikan antara jenis media massa dengan pengetahuan kesehatan reproduksi pada remaja. Hasil penelitian ini didapatkan bahwa sebagian besar siswa yang jenis media massanya berpengaruh memiliki pengetahuan kesehatan reproduksi cukup $(35,6 \%)$ dan baik $(26,7 \%)$ sedangkan siswa yang jenis media massanya tidak berpengaruh pada umumnya memiliki pengetahuan kesehatan reproduksi cukup $(24,4 \%)$ dan kurang $(13,3 \%)$ dengan nilai signifikan $\mathrm{p}$ adalah $0,002$ ( $\mathrm{p}<0,05)$. Hasil penelitian ini sesuai dengan hasil penelitian sebelumnya oleh Nasria Putriani (2010) yang menyatakan bahwa faktor-faktor yang mempengaruhi pengetahuan remaja tentang kesehatan reproduksi berdasarkan informasi kesehatan reproduksi, sumber kesehatan reproduksi melalui internet, majalah dengan hasil pengetahuannya termasuk dalam kategori baik. Hasil penelitian ini juga sesuai dengan hasil penelitian sebelumnya oleh Addisi Dyah (2009) yang menyatakan bahwa ada hubungan banyaknya media massa dengan tingkat pengetahuan kesehatan reproduksi pada remaja (Addisi, 2009).

Berdasarkan hasil penelitian yang signifikan dan kesesuaian dengan teori dan hasil penelitian sebelumnya maka dapat disimpulkan bahwa terdapat hubungan jenis media massa dengan pengetahuan kesehatan reproduksi pada remaja. Seiring dengan perkembangan teknologi saat ini membuat jenis media massa yang berkembang di masyarakat semakin beragam, oleh karena itu semakin banyaknya jenis media massa yang digunakan, semakin banyak juga pengetahuan tentang kesehatan reproduksi yang di peroleh. 


\section{KESIMPULAN}

Terdapat hubungan akses media massa dengan pengetahuan kesehatan reproduksi dan terdapat hubungan jenis media massa dengan pengetahuan kesehatan reproduksi.

\section{DAFTAR ISI}

Basri,hasan. Remaja Berkualitas Problematika Remaja dan Solusinya. Yogyakarta : Pustaka Pelajar. 1996

Nasria. Skripsi : Faktor-faktor yang Mempengaruhi Pengetahuan Remaja tentang Kesehatan Repproduksi di SMA Negeri 1 Mojogedang. Semarang. Undip. 2010

Tri. Tesis : Faktor-Faktor Yang Mempengaruhi Terhadap Praktek Kesehatan reproduksi Remaja di SMA Negeri 1 Purbalingga Kabupaten Purbalingga. Semarang. Undip. 2008

Bagus,ida. Demografi Umum. Pustaka Pelajar. 2004

Rizza. Skripsi : Hubungan PenggunaanMedia Massa dengan Tingkat Pengetahuan Kesehatan Reproduksi pada Remaja di SMA $N 8$ Surakarta. Semarang. Undip. 2011

Addisi. Skripsi : Hubungan Banyaknya Media Massa dengan Tingkat PengetahuanKesehatan Reproduksi pada Remaja di SMU Negeri 5 Madiun. Semarang. Undip. 2009

Notoadmodjo.Definisi Pengetahuan dan Faktor-faktor yang Mempengaruhi Pengetahuan. Available from : www.duniabaca.com/definisi-

pengetahuanserta-faktor-faktoryang-mempengaruhipengetahuan.html. 2010

Latief abdul,dkk. Buku Kuliah Ilmu Kesehatan Anak FK UI. Jakarta : Infomedika. 1985
BEM FK UNDIP. Ilmu Kesehatan Kulit dan Kelamin. Semarang : BEM FK UNDIP. 2005

Suhanjati. TV dan Internet Beri Andil Meledaknya Seks Pranikah. Suara Merdeka. 13 Oktober 2003 